\title{
Effects of Glomus lamellosum on Growth, Essential Oil Production and Nutrients Uptake in Selected Medicinal Plants
}

\author{
Nikitas Karagiannidis, Thomas Thomidis (Corresponding author) \& Eleni Panou-Filotheou \\ Alexander Technological Education Institute of Thessaloniki, Department of Crop Production \\ 57400, Sindos Macedonia, Greece \\ Tel: 30-231-001-3768_E-mail: thomi-1@otenet.gr, thomidis@cp.teithe.gr
}

$\begin{array}{lc}\text { Received: August 3,2011 Accepted: August 18, } 2011 \quad \text { Online Published: December 29, } 2011 \\ \text { doi:10.5539/jas.v4n3p137 } & \text { URL: http://dx.doi.org/10.5539/jas.v4n3p137 }\end{array}$

\begin{abstract}
The effect of Glomus lamellosum on root colonization, growth, essential oil production and composition and nutrient acquisition of Santolina chamaecyparissus, Salvia officinalis, Lavandula angustifolia, Geranium dissectum, and Origanum dictamnus was investigated. The results showed that mycorrhizal plants had significantly higher growth, essential oil production and nutrient contents compared to non-inoculated plants. The $S$. officinalis plants showed the highest percentage of colonization, while the $S$. chamaecyparissus the lowest. Similar percentage of colonization was found among the G. dissectum, L. angustifolia and O. dictamnus plants. Analysis of essential oil by GC and GC/MS showed that the effect of G. lamellosum on the main compounds in leaf essential oils was different on the plant species used.

It is concluded that the use of Glomus lamellosum may allow plant growth in low fertility soils, reduce fertilizer inputs and increase aromatic plant production of essential oils, while they indicate that it may be possible to use mycorrhizae to affect the quality of the essential oil produced.
\end{abstract}

Keywords: Arbuscular mycorrhizal fungus, Colonization, Geranium dissectum, Lavandula angustifolia, Origanum dictamnus, Salvia officinalis, Santolina chamaecyparissus

\section{Introduction}

Medicinal herbs are known as sources of phytochemicals, or active compounds that are widely sought after worldwide for their natural properties. They are useful source of essential oil and have been used for a long time in the perfumery, cosmetic, food and pharmaceutical industry. Essential oils are volatile, lipophilic mixtures of secondary plant compounds, mostly consisting of monoterpenes, sesquiterpenes and phenylproponoids. The qualitative and quantitative improvement of essential oil production presents an area of high commercial interest (Copetta et al., 2006; Khaosaad et al., 2006).

The arbuscular mycorrhizal symbiosis is recognized for its multiple positive effects on plant growth and for its important contribution towards the maintenance of soil quality. In spite of these benefits to agriculture, at present, the realization of the full potential of this symbiosis has not yet been reached. The understanding of interactions existing among crops, fungal partners and environmental conditions must improve to allow for the efficient management of the mycorrhizal symbiosis through selected agronomic practices and inoculation of cultivated crops (Hamel, 1996).

Arbuscular mycorrhizal fungi (AMF) are a ubiquitous group of soil fungi colonizing the roots of plants belonging to more than $90 \%$ of plant families (Brundett, 1991). Enhanced plant growth due to AMF association is well documented (Bagyaraj, 1984). In the past few decades, AMF have emerged as potential biofertilisers, a cheap, environmentally friendly alternative to expensive chemical fertilizers (Srivastava et al., 1996). These fungi are known to improve the nutritional status of the host, particularly that of phosphorous, and thereby enhance their growth, development and yield (Bagyaraj and Varma, 1995). Many other aspects of arbuscular mycorrhizal interactions including biocontrol toward plant pathogens, tolerance to water stress and adverse environmental conditions were studied, but little is known about their potential effect on the quantitative and qualitative profile of the secondary metabolites (e.g., essential oils) in medicinal and aromatic plants (Kapoor et al., 2002; Copetta et al., 2006; Morone-Fortunato \& Avato, 2008). 
During the establishment of the arbuscular mycorrhizal symbiosis, a range of chemical and biological parameters is affected in plants, including the pattern of secondary compounds. However, little is known about the effect of AMF upon either plant secondary metabolic pathways or the production and yield of secondary compounds of their hosts (Copetta et al., 2006). For instance, studies have demonstrated that AMF can influence phytohormone levels of (Hause et al., 2002) terpenoids and carotenoids (Fester et al., 2002) and phenols (Zhu and Yao, 2004). In addition, the association with AMF has altered essential oil yield and quality of several plants (Kapoor et al., 2002).

Though not host specific, earlier studies have indicated host preferences of mycorrhizal fungi (Miller et al., 1987), thus suggesting the need for selecting efficient AMF for a particular host (Sailo and Bagyaraj, 2005).

The objective of this paper is a comparative analysis of the effects induced by the arbuscular mycorrhizal fungus, G. lamellosum on plant growth, nutrient uptake and essential oil production and composition of Santolina chamaecyparissus, Salvia officinalis, L. angustifolia, Geranium dissectum, and O. dictamnus.

\section{Materials and Methods}

\subsection{Isolates}

A strain of G. lamellosum, isolated from oregano plant collected from Elatochori, Pieria, Greece, was used in this study. Identification was made by using the molecular method described by Karagiannidis et al. (2011) and retained on mother maize plants.

\subsection{Effect of Glomus lamellosum on five medical plants}

Plants of Santolina chamaecyparissus, Salvia. officinalis, L. angustifolia, G. dissectum, and O. dictamnus were propagated by stem cuttings (originated from the mother plantations established in the experimental field of Alexander Technological Education Institute of Thessaloniki) rooted in autoclaved perlite in the greenhouse under a misting system. The rooted cuttings were transplanted in April in pots containing $1.5 \mathrm{~kg}$ of soil substrate mixed with fine cut pieces of highly colonized roots of maize plants with a pure G. lamellosum strain following the method described by Karagiannidis (1980). For the mycorrhizal treatments, $10 \mathrm{~cm}^{3}$ inoculum per pot (about $12 \mathrm{~g}$ ) was placed in the planting hole beneath the plants at transplanting. The inoculum consisted of colonized root fragments (roots were cut into $1 \mathrm{~cm}$ pieces), hyphae and spores. Pots without inoculum were used as control. The soil used was a sandy loam with a $\mathrm{pH} 6.5$; low salinity $(0.82 \mathrm{mS}$ conductivity), low organic matter $(0.6 \%)$, low $\mathrm{CaCO}_{3}(0.11 \%)$ with a $\mathrm{Ca}, \mathrm{Mg}$ and $\mathrm{P}$ content at $152,9.6$, and $0.7 \mathrm{mg} / \mathrm{kg}$ respectively and it was autoclaved at $120{ }^{\circ} \mathrm{C}$ for 25 minutes. A fertilization treatment with $25.4 \mathrm{mg} \mathrm{kg}{ }^{-1} \mathrm{KCl}, 29.7 \mathrm{mg} \mathrm{kg}^{-1} \mathrm{~K}_{2} \mathrm{SO}_{4}, 162 \mathrm{mg} \mathrm{kg}^{-1}$ $\mathrm{Ca}_{5}\left(\mathrm{PO}_{4}\right)_{3} \mathrm{OH}, 27.6 \mathrm{mg} \mathrm{kg}^{-1} \mathrm{MgCl}_{2} \cdot 6 \mathrm{H}_{2} \mathrm{O}$ and $190 \mathrm{mg} \mathrm{kg}^{-1} \mathrm{NH}_{4} \mathrm{NO}_{3}$ was added to the potting mix before planting.

A total of 200 pots were used with the following combinations: 2 inoculation treatments (inoculated plants with G. lamellosum; non-inoculated control) replicated 4 times of 5 pots for each of the plant host species evaluated. Plants were grown in a random design for 2.5 months in the greenhouse.

Shoots and roots were harvested separately to analyse nutrient and essential oil composition in the shoots and the establishment of the arbuscular mycorrhizal symbiosis in the roots. The shoots were air-dried for three days (10\% moisture content) and nutrients were analysed after mineralization by calcination in a muffle furnace at $450^{\circ} \mathrm{C}$ for 8 hours, and extraction with $\mathrm{HCl}(35 \%)$. Na and $\mathrm{K}$ were determined using flame photometry. $\mathrm{N}$ was determined using the Kjeldahl method, $\mathrm{P}$ was determined using chromatography and $\mathrm{Ca}$ and $\mathrm{Mg}$ were determined volumetrically using the Versanate method. Concentration of trace elements was determined with atomic absorption spectrophotometry ( $\mathrm{Fe}, \mathrm{Mn}, \mathrm{Cu}, \mathrm{Zn})$ and $\mathrm{B}$ with the azomethine. All methods are described in Jackson (1960) and Cottenie (1980).

Roots were stained with trypan blue (Sylvia, 1994) and mycorrhizal colonization was estimated according to McGonigle et al. (1990).

Leaves were separated from shoots, and the essential oils were obtained by hydrodistillation in $500 \mathrm{~mL} \mathrm{H}_{2} \mathrm{O}$ in a Clevenger apparatus for 2 hours. The composition of the volatile constituents was established by GC and GC-MS analyses. GC analyses were performed on a Shimadzu GC-14A, with a FID (Flame Ionization Detector), using a DB5 column $(30 \mathrm{~m} \times 0.25 \mathrm{~mm}$, film thickness: $0.25 \mathrm{~m})$, The temperature program was from $65^{\circ} \mathrm{C}$ for 10 $\mathrm{min}$, to $160^{\circ} \mathrm{C}$ at a rate of $3{ }^{\circ} \mathrm{C} / \mathrm{min}$ for $5 \mathrm{~min}$. Helium was used as a carrier gas at a flow rate of $0.6 \mathrm{ml} / \mathrm{min}$.

GC-MS analyses were performed on a Shimadzu GC-2010-GCMS-QP2010 system operating in EI mode (70eV) equipped with a split/splitless injector $\left(230^{\circ} \mathrm{C}\right)$, a split ratio $1 / 30$, using a fused silica HP-5 MS capillary column (30 m x $0.25 \mathrm{~mm}$ (i.d.), film thickness: $0.25 \mu \mathrm{m}$ ) and a polar column HP-Innowax. The analytical conditions were: for the HP-5MS column the temperature program was from $60^{\circ} \mathrm{C}(5 \mathrm{~min})$ to $280^{\circ} \mathrm{C}$ at a rate of $4^{\circ} \mathrm{C} / \mathrm{min}$ and for the HP-Innowax column the temperature program was from $60^{\circ} \mathrm{C}(5 \mathrm{~min})$ to $260^{\circ} \mathrm{C}$ at a rate of $3^{\circ} \mathrm{C} / \mathrm{min}$. 
Helium was used as a carrier gas at a flow rate of $0.8 \mathrm{ml} / \mathrm{min}$. Injection volume of each sample was $1 \mu \mathrm{l}$. Retention indices for all compounds were determined using n-alkanes as standards. The identification of the components was based on comparison of their MS with those of NIST21 and NIST107 and those described by Adams (2001). Quantitative determination was based on the total ion count detected by the GC-MS.

This experiment was repeated.

\subsection{Statistical analysis}

Statistical analysis of the data was carried out by using analysis of variance. Means were separated by using the Duncan's multiple range test at 0.05 significance level.

\section{Results and Discussion}

The results of mycorrhizal inoculation resulted in a significant increase in growth, nutrient contents and essential oil productions in all plant species used (Table 1). Improved plant growth, nutrients uptake and essential oil production was evident because arbuscular mycorrhizal fungal inoculation has previously been reported in mychorrizal aromatic plants (Boby and Bagyaraj, 2003; Tharun et al., 2006; Geneva et al., 2010; Karagiannidis et al., 2010). In this study, plant biomass (shoot + root) was enhanced by $33.33 \%, 44.35 \%, 46.72 \%, 24.9 \%$, $25.27 \%$ in arbuscular mycorrhizal Santolina chamaecyparissus, Salvia officinalis, L. angustifolia, G. dissectum and O. dictamnus plants, respectively (Table 1). According to Geneva et al., (2010) arbuscular mycorrhizal colonization on Salvia officinalis improved the growth of plants. Nowak (2004) found that mycorrhizal inoculation of geranium increased the growth of plants. Previous works showed that increased plant growth due to AMF inoculation is mainly through improved uptake of diffusion limited nutrients such as P (Lambert et al., 1979; Sailo and Bagyaraj, 2005) and those findings are in good agreement with the results of this study in which all the arbuscular mycorrhizal plants had significant higher nutrient contents in comparison to uninoculated treatment. The contents of $\mathrm{N}, \mathrm{P}, \mathrm{Ca}, \mathrm{Mg}, \mathrm{B}, \mathrm{Zn}, \mathrm{Fe}, \mathrm{Cu}$ and $\mathrm{Mn}$ were significantly higher in all mycorrhizae applied plants compared to control ones, while the Santolina chamaecyparissus, Salvia. officinalis and $O$. dictamnus mycorrhizal plants had significant higher $\mathrm{K}$ and $\mathrm{Na}$ contents than uninoculated treatments (Table 2). The mycorrhizal and non-mycorrhizal G. dissectum plants had similar K and Na contents. The content of K was significantly higher in mycorrhizal plants of L. angustifolia, while the $\mathrm{Na}$ content was similar in both mycorrhizal and nonmycorrhizal plants. Such higher nutrient content in AMF inoculated plants is attributed to higher influx of nutrients into the plant system through AMF which explores the soil volume beyond depletion zone as previous works showed for P (Sanders and Tinker, 1971; Bayaraj and Varma, 1995). According to Bagyaraj and Reddy (2000) the extramatrical hyphae produced by AMF act as extensions of roots and increase the surface area of the root system, making it more efficient for absorption of water and diffusion limited nutrients, this effect being more pronounced in P-deficient soils. Previous works have shown that AMF increase plant uptake of phosphate (Bolan, 1991), micronutrients (Burkert and Robson, 1994), nitrogen (Barea et al., 1991). Moreover, it has been demonstrated that plants inoculated with AMF utilize more soluble phosphate from rock phosphate than noninoculated plants (Antunes \& Cardoso, 1991).

The Salvia officinalis plants showed the highest percentage of colonization, while the Santolina chamaecyparissus the lowest (Table 1). Similar percentage of colonization was found among the G. dissectum, $L$. angustifolia and O. dictamnus plants. Karthikeyan et al. (2009) inoculated Ocimum sanctum, Catharanthus roseus, Coleus forskholii and Cymbopogon flexuosus plants with the mycorrhizal fungus G. fasciculatum and found similar situation in all the four medicinal plants, which recorded 58 to $75 \%$ vesicular arbuscular mycorrhizal association.

The essential oil production in arbuscular mycorrhizal plants was significantly increased in all plant species tested compared to the uninoculated treatment (Table 1). Specifically, the essential oil production was enhanced by $28.75 \%, 55.56 \%, 56.95 \%, 53.63 \%, 55.24 \%$ in arbuscular mycorrhizal Santolina. chamaecyparissus, Salvia officinalis, $L$. angustifolia, $G$. dissectum and $O$. dictamnus plants respectively (Table 1 ). The favorable effect of root colonization of Salvia officinalis by Glomus intraradices was determined both on quantitative and qualitative pattern of sage essential oil (Geneva et al., 2010). Venkateshwar et al. (2002) found that rose-scented geranium plants inoculated with one of Acaulospora laevis, Gigaspora margarita, G. fasciculatum or G. mosseae recorded significantly higher essential oil yield (21.1\%) in comparison to non-mycorrhizal plants.

Although analysis of essential oil by GC and GC/MS showed that mycorrhizal inoculation influenced the plant species differently, the results show only very small differences in volatile composition between mycorrhizal and non-mycorrhizal plants in all species. The major volatile constituents in each species did not differ significantly between mycorrhizal and non-mycorrhizal plants. The two volatiles that are found in all plant species show either no change between mycorrhizal treatments ( $\beta$-myrcene), or no change or decrease in abundance (a-pinene) 
with mycorrhizal inoculation. In Salvia officinalis, the compound Carvacrol + Geranyl formate was detected only in arbuscular mycorrhizal plants, while the compounds Lemonene and Geranyl acetate only in noninoculated plants. The compounds $\beta$-Pinene, and 1,8-Cineole were significantly higher in noninoculated than inoculated plants. In contrast the compounds Camphor and Bornyl acetate were significantly higher in inoculated plants (Table 3). In G. dissectum, the concentation of the compound Spathulenol was significantly higher in noninoculated than inoculated plants. Only trace of Terpinen-4-ol was detected in AM plants, while only trace of the $\alpha$-Caryophyllene, allo-Aromadendrene, $\beta$-Bisabolene, Geranyl isobutanoate, 1,10-di-epi-Cubenol, 1-epi-Cubenol, $\gamma$-Eudesmol were detected in noninoculated plants. In L. angustifolia, the concentration of trans-Pinocarveol was significantly higher in noninoculated than inoculated plants. The compounds Octen-3-ol, Geranyl acetate, Terpinolene were detected only in trace in noninoculated L. angustifolia plants. In $S$. chamaecyparissus, the concentration of the compounds Bornoel and Caryophyllene oxide were significantly higher in noninoculated than inoculated plants. In O. dictamnus, only the AM plants had some amounts of the compound $\beta$-Phellandrene, while the compounds $\beta$-Cubebene, $\beta$-Bisabolene, $\delta$-Cadinene were detected only in noninoculated plants. Information about the effects of AMF on the production of essential oils is scarce and only a few papers concerning a limited choice of species have been published up to now. Copetta et al. (2006) compared different AMF inoculation on basil and found that AMF induced various modifications in the considered parameters. Geneva et al. (2010) found that the G. intraradices inoculation of Salvia officinalis in combination with fertilization promoted the production of 1,8-cineole and alpha-thujone, mycorrhizal colonization enhanced bornyl acetate, 1,8-cineole, alpha- and beta-thujones. Kapoor et al. (2002) observed that inoculation with AMF $G$. macrocarpum and $G$.fasciculatum increased significantly the concentration of limonene and $\alpha$-phellandrene, respectively, relative to non-mycorrhizal control plants of Anethum graveolens L. Kapoor et al. (2004) also observed enhanced concentration and quality of essential oils on mycorrhizal Coriandrum sativum L (coriander) and Foeniculum vulgare. Mill. (fennel). For Mentha arvensis L. (mint) mycorrhizal colonization significantly increases oil content and yield relative to non-mycorrhizal plants (Gupta et al., 2002). Freitas et al. (2004) also observed that inoculation with AMF resulted in increments of $89 \%$ in the essential oil and menthol contents of mint.

\section{Conclusions}

Generally, Santolina chamaecyparissus, Salvia officinalis, L. angustifolia, dissectum G. dissectum, and $O$. dictamnus plants resulted in bigger plants with greater yield, had a higher essential oils production and nutrient elements when mycorrhizal, but mycorrhizal inoculation did not exert a significant effect on volatile composition. These results indicate the importance of the AM symbiosis, that should be managed to help in the reduction of fertiliser and other agrochemical inputs, thus enhancing the sustainability of the commercial cultivation of aromatic plants, even in low fertility, mountainous soils.

\section{References}

Adams, R.P. (2001). Identification of essential oil compounds by GC quadrupole mass-spectometry. Allured Publishing Corporation, Carol Stream, Ill, USA, Pp 125-129.

Antunes, V., \& Cardoso, E.J. (1991). Growth and nutrient status of citrus plants as influenced by mycorrhiza and phosphorus application. Plant and Soil, 131, 11-19. http://dx.doi.org/10.1007/BF00010415

Bagyaraj, D.J. (1984). Biological interactions with VA mycorrhizal fungi. In: VA Mycorrhiza. Eds., Powell, C.L. and D.J. Bagyaraj. CRC Press, Boca Raton, FL, USA, pp: 131-153.

Bagyaraj, D.J., \& Reddy, B.J.D. (2000). Arbuscular mycorrhizas in sustainable agriculture. In: Microbial biotechnology for sustainable development and productivity. Ed., Rajak, R.C. Scientific Pub., Jodhpur, India, pp: 43-53.

Bagyaraj, D.J., \& Varma, A. (1995). Interactions between arbuscular mycorrhizal fungi and plants: their importance in sustainable agriculture in arid and semiarid tropics. Advances in Microbial Ecology, 14, 119-142.

Barea, J.M., El-Atrach, F., \& Azcon, R. (1991). The role of VA mycorrhizas in improving plant N acquisition from soil as assessed with $15 \mathrm{~N}$. The use of stable isotopes in plant nutrition, In: Fitton C, (ed.) Soil Fertility and Environmental Studies, Joint AIEA, FAO, Division, Vienna, pp. 677-808.

Boby, V.U., \& Bagyaraj, D.J. (2003). Biological control of root-rot of Coleus forskholii Briq. using microbial inoculants. World Journal of Microbiology and Biotechnology, 19, 175-180, http://dx.doi.org/10.1023/A:1023238908028

Bolan, N.S. (1991). A critical review on the role of mycorrhizal fungi in the uptake of phosphorus by plant. Plant and Soil, 134, 189-207. http://dx.doi.org/10.1007/BF00012037 
Brundett, M. (1991). Mycorrhizas in natural ecosystems. Advances in Ecological Research, 21,171-313.

Burkert, B., \& Robson, A. (1994). Zn uptake in subterranean clover (Trifolium subterraneum) by three vesicular-arbuscular mycorrhizal fungi in a root free sandy soil. Soil Biology and Biochemistry, 26, 1117-1124. http://dx.doi.org/10.1016/0038-0717(94)90133-3

Copetta, A., Lingua, G., \& Berta G. (2006). Effects of three AM fungi on growth, distribution of glandular hairs, and essential oil production in Ocimum basilicum L. var. Genovese. Mycorrhiza, 16, 485-494. http://dx.doi.org/10.1007/s00572-006-0065-6

Cottenie, A. (1980). Soil and plant testing as a basis of fertilizers recommendation. F.A.O. Soil Bulletin, 38, p. 96, Rome.

Fester, T., Schmidt, D., Lohse, S., Walter, M.H., Guiliano, G., Bramley, P.M., Frase, P.D., Hause, B., \& Strack, D. (2002). Stimulation of carotenoied metabolism in arbuscular mycorrhizal roots. Planta, 216,148-154. http://dx.doi.org/10.1007/s00425-002-0917-z

Freitas, M.S.M., Martins, M.A., \& Vieira, I.J.C. (2004). Produção equalidade de óleos essenciais de Mentha arvensis emresposta a inoculação de fungos micorrízicos arbusculares. Pesquisa Agropecuária Brasileira, 39, 887-894. http://dx.doi.org/10.1590/S0100-204X2004000900008

Geneva, M.P., Stancheva, I.V., Boychinova, M.M., Mincheva, N.H., \& Yonova, P.A. (2010). Effects of foliar fertilization and arbuscular mycorrhizal colonization on Salvia officinalis L. growth, antioxidant capacity, and essential oil composition. Journal of Science, Food and Agriculture, 90, 696-702. http://dx.doi.org/10.1002/jsfa.3871

Gupta, M.L., Prasad, A., Ram, M., \& Kumar, S. (2002). Effect of the vesicular-arbuscular mycorrhizal (VAM) fungus Glomus fasciculatum on the essential oil yield related characters and nutrient acquisition in the crops of different cultivars of menthol mint (Mentha arvensis) under field conditions. Bioresoures Technology, 81, 77-79. http://dx.doi.org/10.1016/S0960-8524(01)00109-2

Hamel, C. (1996). Prospects and problems pertaining to the management of arbuscular mycorrhizae in $\begin{array}{lllll}\text { agriculture. Agrultural Ecosystem \& } \quad \text { Environment, } & 60, & 197-210 .\end{array}$ http://dx.doi.org/10.1016/S0167-8809(96)01071-7

Hause, B., Maier, W., Miersch, O., Kramell, R. \& Strack, D. (2002). Induction of jasmonate biosynthesis in arbuscular mycorrhizal barley roots. Plant Physiology, 130, 1213-1220. http://dx.doi.org/10.1104/pp.006007

Jackson, M.L. (1960). Soil Chemical Analysis. Prentice Hall Inc. Engwood, p.131.

Kapoor, R., Giri, B., \& Mukerji, K.G. (2002). Glomus macrocarpum, a potential bioinoculant to improve essential oil quality and concentration in dill (Anethum graveolens L.) and carum (Trachyspermum ammi L. Sprague). World Journal of Microbiology and Biotechnology, 18, 459-463. http://dx.doi.org/10.1023/A:1015522100497

Kapoor, R., Giri, B., \& Mukerji, K.G. (2004). Improved growth and essential oil yield and quality in Foeniculum vulgare mill on mycorrhizal inoculation supplemented with P-fertilizer. Bioresoures Technology, 93, 300-311. http://dx.doi.org/10.1016/j.biortech.2003.10.028

Karagiannidis, N. (1980). Untersuchungen über die Effizienz der vesikulär arbuskulären (VA-) Mykorrhiza verschiedener Herkunft bei unterschiedlichen tropischen und subtropischen Pflanzen, Phosphat-formen, Boden-pH-Werten und Bodentemperaturen. Dissertation Göttingen

Karagiannidis, N., Panou-Filotheou, E., Lazari, D., Ipsilantis, I., \& Karagiannidou, C. (2010). Essential oil content and composition, nutrient and mycorrhizal status of some aromatic and medicinal plants of northern Greece. Natural Products, Communication, 5, 823-830.

Karagiannidis, N., Thomidis, T., Lazari, D., Panou-Filotheou, E., \& Karagiannidou, C. (2011). Effect of three Greek arbuscular mycorrhizal fungi in improving the growth, nutrient concentration, and production of essential oils of oregano and mint plants. Scientia Horticulturae, 129, 329-334. http://dx.doi.org/10.1016/j.scienta.2011.03.043

Karthikeyan, B., Joe, M.M., \& Jaleel, C.A. (2009). Response of Some Medicinal Plants to Vesicular Arbuscular Mycorrhizal Inoculations. Journal of Scientific Research, 1, 381-386. http://dx.doi.org/10.3329/jsr.v1i2.1675

Khaosaad, T., Vierheilig, H., Zitterl-Eglseer, K., \& Novak, J. (2006). Arbuscular mycorrhiza alters the concentration of essential oils in oregano (Origanum sp., Lamiaceae). Mycorrhiza, 16, 443-446. http://dx.doi.org/10.1007/s00572-006-0062-9 
Lambert, D.H., Baker, D.E., \& Cole, H. (1979). The role of mycorrhizae in the interaction of phosphorus with zinc, copper and other elements. Soil Science and Society of American Journal, 43, 976-980.

McGonigle, T.P., Miller, M.H., Evans, D.G., Fairchild, G.S., \& Swan, J.A. (1990). A new method which gives an objective measure of colonization of roots by vesicular-arbuscular mycorrhizal fungi. New Phytologist, 115, 495-501. http://dx.doi.org/10.1111/j.1469-8137.1990.tb00476.x

Miller, R.M., Jarstfer, A.G., \& Pillai, J.K. (1987). Biomass allocation in an Agropyron smithi- Glomus symbiosis. American Journal of Botany, 74, 114-122. http://dx.doi.org/10.2307/2444337

Morone-Fortunato, I., \& Avato, P. (2008). Plant development and synthesis of essential oils in micropropagated and mycorrhiza inoculated plants of Origanum vulgare L. ssp. Hirtum (Link) Ietswaart. Plant Cell Tissues, Organ Culture, 93, 139-149. http://dx.doi.org/10.1007/s11240-008-9353-5

Nowak, J. (2004). Effects of arbuscular mycorrhizal fungi and organic fertilization on growth, flowering, nutrient uptake, photosynthesis and transpiration of geranium (Pelargonium hortorum L.H. Bailey 'Tango Orange'). Symbiosis, 37, 259-266.

Sailo, L.G., \& Bagyaraj, D.J. (2005). Influence of different AM fungi on growth, nutrition and forskolin content of Coleus forskohlii. Mycological Research, 109, 795-798. http://dx.doi.org/10.1017/S0953756205002832

Sanders, F.E., \& Tinker, P.B. (1971). Mechanism of absorption of phosphate from soil by Endogone mycorrhizas. Nature, 233, 278-279.

Srivastava, D., Kapoor, R., Srivastava, A.K., \& Mukerji, K.G. (1996). Vesicular arbuscular mycorrhiza, an overview. In: Mukerji KG (ed) Concepts in mycorrhizal research. Kluwer, Dordrecht, pp. 1-34.

Sylvia, D.M. (1994). Vesicular-arbuscular mycorrhizal (VAM) fungi. In Methods of soil analysis, Part 2. Microbiological and biochemical properties, Weaver RW, Angle JS, Bottomley PJ, Bezdicek D, Smith S, Tabatabai A, Wollum AG. (Eds). Soil Science Society of America, Madison, WI, 351-378

Tharun, C., Bagyaraj, D.J., \& Patil, C.S.P. (2006). Response of Andrographis paniculata to different arbuscular mycorrhizal fungi. Journal of Agricultural Technology, 2, 221-228.

Venkateshwar Rao, G., Manoharachary, C., \& Rajeswara Rao, B.R. (2002). Beneficial influence of arbuscular mycorrhizal fungal association on growth, yield and nutrient uptake of rose-scented geranium (Pelargonium species). Philippine Journal of Science, 131, 49-58.

Zhu, H.H., \& Yao, Q. (2004). Localized and systematic increaseof phenols in tomato roots induced by Glomus versiforme inhibits Ralstonia solanacearum. Journal of Phytopathology, 152, 537-542. http://dx.doi.org/10.1111/j.1439-0434.2004.00892.x

Table 1. Dry weight, essential oil production, and percentage of root colonization of Santolina chamaecyparissus, Salvia officinalis, Lavandula angustifolia, Geranium dissectum, and Origanum dictamnus inoculated with the indigenous Glomus lamellosum

\begin{tabular}{|c|c|c|c|c|c|c|c|}
\hline \multirow{3}{*}{$\begin{array}{l}\text { Plant Species } \\
\text { S. chamaecyparissus }\end{array}$} & \multirow{2}{*}{$\mathrm{M}^{\mathrm{x}}$} & \multicolumn{2}{|c|}{ Dry Weight (g) } & \multicolumn{2}{|c|}{ Essential Oil Production (\%) } & \multicolumn{2}{|c|}{ Colonization (\%) } \\
\hline & & $42.49^{\mathrm{y}}$ & $a^{2}$ & 0.80 & $\mathrm{a}$ & 38 & $\mathrm{C}$ \\
\hline & NM & 14.16 & $\mathrm{~b}$ & 0.23 & $\mathrm{~b}$ & & \\
\hline \multirow[b]{2}{*}{ S. officinalis } & $\mathrm{M}$ & 25.57 & $\mathrm{a}$ & 1.17 & $\mathrm{a}$ & 83 & A \\
\hline & NM & 11.34 & $\mathrm{~b}$ & 0.65 & $\frac{a}{b}$ & & \\
\hline & & & & & & & \\
\hline \multirow{2}{*}{ L. angustifolia } & $\mathrm{M}$ & 39.62 & $\mathrm{a}$ & 2.23 & $\mathrm{a}$ & 52 & $\mathrm{~B}$ \\
\hline & NM & 18.51 & $\mathrm{~b}$ & 1.27 & $\mathrm{~b}$ & & \\
\hline \multirow{2}{*}{ G. dissectum } & M & 51.72 & $\mathrm{a}$ & 4.27 & $\mathrm{a}$ & 64 & B \\
\hline & NM & 12.88 & $\mathrm{~b}$ & 2.29 & $\mathrm{~b}$ & & \\
\hline \multirow{2}{*}{ O. dictamnus } & $\mathrm{M}$ & 33.72 & $\mathrm{a}$ & 5.25 & $\mathrm{a}$ & 68 & B \\
\hline & NM & 8.52 & $\mathrm{~b}$ & 2.90 & $\mathrm{~b}$ & & \\
\hline
\end{tabular}

${ }^{\mathrm{x}} \mathrm{M}=$ Mycorrhizal Plants, NM = Non-mycorrhizal plants

${ }^{y}$ Values are the means of 2 experiments, each with 4 replicates; results were similar according to the Bartletts's test of homogeneity of variance, so data were combined

${ }^{z}$ Values in the same column followed by different letters are significantly different $(P=0.05)$ according to Duncan's Multiple Range Test. 
Table 2. Nutrient concentration in Santolina chamaecyparissus, Salvia officinalis, Lavandula angustifolia,

Geranium dissectum, and Origanum dictamnus plants inoculated with the indigenous Glomus lamellosum

\begin{tabular}{|c|c|c|c|c|c|c|c|c|c|c|c|c|c|c|c|c|c|c|c|c|c|c|c|}
\hline Plant Species & & \multicolumn{2}{|c|}{$\mathrm{N}(\%)$} & \multicolumn{2}{|c|}{$\mathrm{P}(\%)$} & \multicolumn{2}{|c|}{$\mathrm{K}(\%)$} & \multicolumn{2}{|c|}{$\mathrm{Na}(\%)$} & \multicolumn{2}{|c|}{$\mathrm{Ca}(\%)$} & \multicolumn{2}{|c|}{$\mathrm{Mg}(\%)$} & \multicolumn{2}{|c|}{$\mathrm{B}\left(\mathrm{mgl}^{-1}\right)$} & \multicolumn{2}{|c|}{$\mathrm{Zn}\left(\mathrm{mgl}^{-1}\right)$} & \multicolumn{2}{|c|}{$\operatorname{Mn}\left(\mathrm{mgl}^{-1}\right)$} & \multicolumn{2}{|c|}{$\mathrm{Fe}\left(\mathrm{mgl}^{-1}\right)$} & \multicolumn{2}{|c|}{$\mathrm{Cu}\left(\mathrm{mgl}^{-1}\right)$} \\
\hline \multirow{2}{*}{ S. chamaecyparissus } & $\mathrm{M}^{\mathrm{x}}$ & $2.68^{y}$ & $a^{2}$ & 0.86 & $\mathrm{a}$ & 3.48 & $\mathrm{a}$ & 3.96 & $\mathrm{a}$ & 1.53 & $\mathrm{a}$ & 0.65 & $\mathrm{a}$ & 57.9 & $\mathrm{a}$ & 122.4 & $\mathrm{a}$ & 167.5 & $\mathrm{a}$ & 560.5 & $\mathrm{a}$ & 59.17 & $\mathrm{a}$ \\
\hline & NM & 0.66 & $\mathrm{~b}$ & 0.11 & $\mathrm{~b}$ & 1.04 & $\mathrm{~b}$ & 1.56 & $\mathrm{~b}$ & 0.65 & $\mathrm{~b}$ & 0.26 & $\mathrm{~b}$ & 21.9 & $\mathrm{~b}$ & 26.4 & $\mathrm{~b}$ & 19.0 & $\mathrm{~b}$ & 104.8 & $\mathrm{~b}$ & 10.20 & $\mathrm{~b}$ \\
\hline & & & & & & & & & & & & & & & & & & & & & & & \\
\hline \multirow{2}{*}{ S. officinalis } & $\mathrm{M}$ & 2.74 & $\mathrm{a}$ & 0.80 & $\mathrm{a}$ & 3.54 & $\mathrm{a}$ & 3.06 & $\mathrm{a}$ & 1.88 & $\mathrm{a}$ & 0.75 & $\mathrm{a}$ & 62.6 & $\mathrm{a}$ & 128.8 & a & 157.1 & a & 499.8 & a & 56.77 & $\mathrm{a}$ \\
\hline & NM & 0.56 & $\mathrm{~b}$ & 0.11 & $\mathrm{~b}$ & 1.12 & $\mathrm{~b}$ & 2.06 & $\mathrm{~b}$ & 0.68 & $\mathrm{~b}$ & 0.37 & $\mathrm{~b}$ & 20.5 & $\mathrm{~b}$ & 18.5 & $\mathrm{~b}$ & 23.8 & $\mathrm{~b}$ & 107.6 & $\mathrm{~b}$ & 9.23 & $\mathrm{~b}$ \\
\hline & & & & & & & & & & & & & & & & & & & & & & & \\
\hline \multirow{2}{*}{ L. angustifolia } & M & 2.46 & $\mathrm{a}$ & 0.75 & $\mathrm{a}$ & 1.87 & $\mathrm{a}$ & 2.87 & $\mathrm{a}$ & 1.46 & $\mathrm{a}$ & 0.59 & $\mathrm{a}$ & 76.4 & $\mathrm{a}$ & 110.1 & $\mathrm{a}$ & 167.2 & $\mathrm{a}$ & 837.7 & $\mathrm{a}$ & 46.50 & $\mathrm{a}$ \\
\hline & $\mathrm{NM}$ & 0.63 & $\mathrm{~b}$ & 0.10 & $\mathrm{~b}$ & 0.96 & $\mathrm{~b}$ & 2.17 & $\mathrm{a}$ & 0.50 & $\mathrm{~b}$ & 0.22 & $\mathrm{~b}$ & 18.1 & $\mathrm{~b}$ & 20.2 & b & 20.5 & b & 88.93 & b & 8.57 & $\mathrm{~b}$ \\
\hline & & & & & & & & & & & & & & & & & & & & & & & \\
\hline \multirow{2}{*}{ G. dissectum } & $\mathrm{M}$ & 2.74 & $\mathrm{a}$ & 0.63 & $\mathrm{a}$ & 1.76 & $\mathrm{a}$ & 2.95 & $\mathrm{a}$ & 1.90 & $\mathrm{a}$ & 0.67 & $\mathrm{a}$ & 70.2 & $\mathrm{a}$ & 121.2 & $\mathrm{a}$ & 176.4 & $\mathrm{a}$ & 568.0 & a & 56.43 & $\mathrm{a}$ \\
\hline & NM & 0.69 & $\mathrm{~b}$ & 0.11 & $\mathrm{~b}$ & 1.19 & $\mathrm{a}$ & 2.24 & $\mathrm{a}$ & 0.68 & $\mathrm{~b}$ & 0.22 & $\mathrm{~b}$ & 21.8 & $\mathrm{~b}$ & 18.0 & $\mathrm{~b}$ & 17.03 & $\mathrm{~b}$ & 121.3 & $\mathrm{~b}$ & 9.47 & $\mathrm{~b}$ \\
\hline & & & & & & & & & & & & & & & & & & & & & & & \\
\hline \multirow{2}{*}{ O. dictammus } & $\mathrm{M}$ & 2.43 & $\mathrm{a}$ & 0.81 & $\mathrm{a}$ & 2.59 & $\mathrm{a}$ & 2.49 & $\mathrm{a}$ & 1.55 & $\mathrm{a}$ & 0.64 & $\mathrm{a}$ & 87.7 & $\mathrm{a}$ & 131.5 & a & 176.5 & a & 378.6 & a & 52.53 & $\mathrm{a}$ \\
\hline & NM & 0.63 & $\mathrm{~b}$ & 0.1 & $\mathrm{~b}$ & 0.9 & $\mathrm{~b}$ & 1.11 & $\mathrm{~b}$ & 0.76 & $\mathrm{~b}$ & 0.31 & $\mathrm{~b}$ & 26.63 & $\mathrm{~b}$ & 24.03 & $\mathrm{~b}$ & 15.7 & $\mathrm{~b}$ & 126.7 & $\mathrm{~b}$ & 13.27 & $\mathrm{~b}$ \\
\hline
\end{tabular}

${ }^{\mathrm{x}} \mathrm{M}=$ mycorrhizal plants, $\mathrm{NM}=$ non-mycorrhizal plants

${ }^{y}$ Values are the means of 2 experiments, each with 4 replicates; results were similar according to the Bartletts's test of homogeneity of variance, so data were combined

${ }^{z}$ Values in the same column followed by different letters are significantly different $(P=0.05)$ according to Duncan's Multiple Range Test.

Table 3. Chemical composition of essential oils of non-mycorrhizal and mycorrhizal Salvia officinalis, Santolina chamaecyparissus, Lavandula angustifolia, Origanum dictamnus and Geranium dissectum plants, inoculated with the indigenous Glomus lamellosum

\begin{tabular}{|c|c|c|c|c|c|c|c|c|c|c|c|c|}
\hline \multirow[t]{2}{*}{ Compounds $^{\mathrm{a}}$} & \multirow[t]{2}{*}{$\mathrm{RI}^{\mathrm{b}}$} & \multicolumn{2}{|c|}{ G.diseectum } & \multicolumn{2}{|c|}{ S. chamaecyparissus } & \multicolumn{2}{|c|}{ S. officinalis } & \multicolumn{2}{|c|}{ O.dictamnus } & \multicolumn{2}{|c|}{ L. officinalis } & \multirow[t]{2}{*}{ Identification $^{\mathrm{C}}$} \\
\hline & & $\mathrm{M}$ & NM & $\mathrm{M}$ & $\mathrm{NM}$ & $\mathrm{M}$ & NM & $\mathrm{M}$ & $\mathrm{NM}$ & $\mathrm{M}$ & NM & \\
\hline$\alpha$-Thujene & 925 & & & & & & & 1.3 & 1.05 & 0.18 & 0.07 & $\mathrm{I}, \mathrm{MS}$ \\
\hline$\alpha$-Pinene & 931 & 0.09 & 0.01 & 0.15 & 0.13 & 0.22 & 1.03 & 0.7 & 0.55 & 1.32 & 0.90 & $\mathrm{I}, \mathrm{MS}, \mathrm{Co}-\mathrm{GC}$ \\
\hline Camphene & 945 & & & 0.56 & 0.42 & 0.52 & 1.45 & & & 0.70 & 0.96 & $\mathrm{I}, \mathrm{MS}$ \\
\hline Sabinene & 970 & & & 4.55 & 3.94 & & & 1.1 & 1.0 & 0.37 & 0.55 & $\mathrm{I}, \mathrm{MS}$ \\
\hline$\beta$-Pinene & 972 & & & 3.71 & 4.06 & $\underline{0.77^{\mathrm{d}}}$ & 2.62 & 0.1 & 0.1 & 1.02 & 0.86 & I, MS, Co-GC \\
\hline Octen-3-ol & 978 & & & & & & & 0.3 & 0.3 & 0.09 & trace & I, MS \\
\hline$\beta$-Myrcene & 990 & 0.10 & 0.06 & 9.60 & 9.84 & 1.56 & 1.52 & 1.7 & 1.55 & 0.78 & 1.03 & $\mathrm{I}, \mathrm{MS}$ \\
\hline$\alpha$-Phellandrene & 1001 & & & 0.21 & 0.14 & & & 0.3 & 0.25 & 0.14 & 0.05 & $\mathrm{I}, \mathrm{MS}$ \\
\hline$p$-Mentha-1(7),8-diene & 1007 & & & & & & & & & 1.12 & 0.64 & $\mathrm{I}, \mathrm{MS}$ \\
\hline$\alpha$-Terpinene & 1014 & & & & & & & 2.8 & 2.5 & 0.32 & 0.89 & $\mathrm{I}, \mathrm{MS}$ \\
\hline$p$-Cymene & 1022 & & & 0.15 & 0.18 & & & 16.4 & 16.25 & 1.81 & 2.62 & I, MS, Co-GC \\
\hline sylvestren & 1025 & & & & & & & & 0.6 & & & $\mathrm{I}, \mathrm{MS}$ \\
\hline$\beta$-Phellandrene & 1026 & 0.07 & 0.02 & 15.05 & 14.33 & 1.42 & 0.55 & 0.6 & & & & $\mathrm{I}, \mathrm{MS}$ \\
\hline Lemonene & 1027 & & & & & & 1.51 & & & & & $\mathrm{I}, \mathrm{MS}$ \\
\hline 1,8-Cineole & 1028 & & & 1.19 & 1.03 & $\underline{16.52}$ & $\underline{19.22}$ & & & 36.22 & 35.91 & $\mathrm{I}, \mathrm{MS}$ \\
\hline cis-Ocimene & 1037 & & & & & & & & & 0.21 & 0.27 & $\mathrm{I}, \mathrm{MS}$ \\
\hline trans-Ocimene & 1047 & & & & & & & & & 0.07 & 0.08 & $\mathrm{I}, \mathrm{MS}$ \\
\hline$\gamma$-Terpinene & 1056 & & & 0.09 & 0.01 & 0.55 & 0.98 & 17.5 & 16.15 & 2.09 & 1.94 & $\mathrm{I}, \mathrm{MS}, \mathrm{Co}-\mathrm{GC}$ \\
\hline Artemisia ketone & 1060 & 0.17 & 0.11 & 36.88 & 35.46 & & & & & 0.08 & 0.06 & $\mathrm{I}, \mathrm{MS}$ \\
\hline cis-Sabinene hydrate & 1064 & & & 0.23 & 0.19 & 0.27 & 0.17 & 0.7 & 0.65 & 0.50 & 0.44 & $\mathrm{I}, \mathrm{MS}$ \\
\hline Terpinolene & 1085 & & & 2.05 & 1.95 & & & 0.1 & 0.1 & 0.10 & trace & $\mathrm{I}, \mathrm{MS}$ \\
\hline 6-Camphenone & 1093 & & & & & & & & & trace & trace & $\mathrm{I}, \mathrm{MS}$ \\
\hline $\begin{array}{c}\text { trans-Sabinene } \\
\text { hydrate }\end{array}$ & 1094 & & & & & & & 0.1 & 0.1 & 0.15 & 0.05 & $\mathrm{I}, \mathrm{MS}$ \\
\hline Linalool & 1097 & 3.82 & 3.91 & & & & & 1.5 & 1.45 & 0.37 & 0.19 & $\mathrm{I}, \mathrm{MS}$ \\
\hline$\alpha$-Thujone & 1102 & & & & & 24.82 & 25.69 & & & & & $\mathrm{I}, \mathrm{MS}$ \\
\hline cis-Rose oxide & 1110 & 0.19 & 0.15 & & & & & & & & & $\mathrm{I}, \mathrm{MS}$ \\
\hline$\beta$-Thujone & & & & & & 4.48 & 4.62 & & & & & $\mathrm{I}, \mathrm{MS}$ \\
\hline trans-Rose oxide & 1127 & 0.08 & 0.02 & & & & & & & & & $\mathrm{I}, \mathrm{MS}$ \\
\hline$\alpha$-Campholenal & 1123 & & & & & & & & & 0.17 & 0.03 & $\mathrm{I}, \mathrm{MS}$ \\
\hline trans-Pinocarveol & 1134 & & & & & & & & & 0.37 & 1.27 & $\mathrm{I}, \mathrm{MS}$ \\
\hline Camphor & 1140 & & & 2.33 & 1.67 & $\underline{25.77}$ & $\underline{17.57}$ & & & 16.07 & 16.94 & $\mathrm{I}, \mathrm{MS}$ \\
\hline Citronellal & 1151 & 0.12 & 0.14 & & & & & & & & & $\mathrm{I}, \mathrm{MS}$ \\
\hline Pinocarvone & 1159 & & & & & & & & & 0.10 & 0.08 & $\mathrm{I}, \mathrm{MS}$ \\
\hline Borneol & 1161 & & & $\underline{1.08}$ & $\underline{2.94}$ & 3.32 & 3.29 & 0.1 & 0.1 & 4.53 & 4.06 & $\mathrm{I}, \mathrm{MS}$ \\
\hline
\end{tabular}




\begin{tabular}{|c|c|c|c|c|c|c|c|c|c|c|c|c|}
\hline Menthol & 1170 & & & & & & & 0.2 & 0.15 & & & $\mathrm{I}, \mathrm{MS}$ \\
\hline iso-Menthone & 1161 & 4.21 & 3.92 & & & & & & & & & $\mathrm{I}, \mathrm{MS}$ \\
\hline Terpinen-4-ol & 1174 & $\mathrm{Tr}$ & 1.01 & 0.22 & 0.31 & & & 0.6 & 0.6 & 0.53 & 0.63 & $\mathrm{I}, \mathrm{MS}$ \\
\hline$p$-Cymen-8-ol & 1181 & & & & & & & & & 0.16 & 0.27 & $\mathrm{I}, \mathrm{MS}$ \\
\hline iso-Menthol & 1183 & 0.08 & 0.07 & & & & & & & & & $\mathrm{I}, \mathrm{MS}$ \\
\hline Cryptone & 1184 & & & & & & & & & 0.92 & 0.94 & $\mathrm{I}, \mathrm{MS}$ \\
\hline$\alpha$-Terpineol & 1187 & 0.17 & 0.11 & & & & & 0.1 & 0.1 & 0.49 & 0.61 & $\mathrm{I}, \mathrm{MS}$ \\
\hline Myrtenal & 1192 & & & & & & & & & 0.44 & 0.37 & $\mathrm{I}, \mathrm{MS}$ \\
\hline trans-carveol & 1218 & & & & & & & & & 0.12 & 0.11 & $\mathrm{I}, \mathrm{MS}$ \\
\hline Citronellol & 1230 & 29.73 & 28.35 & & & & & & & 1.37 & 1.48 & $\mathrm{I}, \mathrm{MS}$ \\
\hline Cumin aldehyde & 1238 & & & & & & & & & 0.59 & 0.24 & $\mathrm{I}, \mathrm{MS}$ \\
\hline Neral & 1238 & 0.59 & 0.71 & & & & & & & & & $\mathrm{I}, \mathrm{MS}$ \\
\hline Carvone & 1241 & & & & & & & & & 0.32 & 0.62 & $\mathrm{I}, \mathrm{MS}$ \\
\hline Geraniol & 1252 & 23.63 & 22.49 & & & & & & & 0.87 & 0.93 & $\mathrm{I}, \mathrm{MS}$ \\
\hline Geranial & 1268 & 1.01 & 1.02 & & & & & & & & & $\mathrm{I}, \mathrm{MS}$ \\
\hline Citronellyl formate & 1275 & 9.87 & 8.64 & & & & & & & 0.43 & 0.33 & $\mathrm{I}, \mathrm{MS}$ \\
\hline Neryl formate & 1282 & 0.06 & 0.02 & & & & & & & & & $\mathrm{I}, \mathrm{MS}$ \\
\hline Bornyl acetate & 1283 & & & & & 9.22 & 2.68 & & & 0.08 & 0.15 & I, MS \\
\hline Thymol & 1289 & 0.07 & 0.01 & & & & & 0.1 & 0.1 & 13.31 & 12.38 & $\mathrm{I}, \mathrm{MS}$ \\
\hline Carvacrol & 1298 & & & 0.95 & 0.34 & & & $\underline{48.3}$ & 51.05 & 5.32 & 4.68 & $\mathrm{I}, \mathrm{MS}$ \\
\hline $\begin{array}{c}\text { Carvacrol + Geranyl } \\
\text { formate }\end{array}$ & 1298 & 11.30 & 12.03 & & & 1.06 & & & & & & $\mathrm{I}, \mathrm{MS}$ \\
\hline$\alpha$-Cubebene & 1348 & & & & & & & 0.2 & 0.2 & & & $\mathrm{I}, \mathrm{MS}$ \\
\hline$\alpha$-Longipinene & 1349 & & & 0.22 & 0.47 & & & & & & & $\mathrm{I}, \mathrm{MS}$ \\
\hline Citronellyl acetate & 1351 & 0.17 & 0.15 & & & & & & & & & $\mathrm{I}, \mathrm{MS}$ \\
\hline$\alpha$-Ylangene & 1373 & 0.06 & 0.09 & & & & & 1.0 & 1.15 & & & $\mathrm{I}, \mathrm{MS}$ \\
\hline Geranyl acetate & 1380 & 1.03 & 1.02 & & & & 6.21 & & & 0.08 & trace & $\mathrm{I}, \mathrm{MS}$ \\
\hline$\beta$-Cubebene & 1388 & & & & & & & & 0.25 & & & I, MS \\
\hline $\begin{array}{l}\text { Phenyl ethyl } \\
\text { isobutanoate }\end{array}$ & 1394 & 0.09 & 0.01 & & & & & & & & & I, MS \\
\hline$\alpha$-Gurjunene & 1409 & & & & & & & & & 0.09 & 0.12 & $\mathrm{I}, \mathrm{MS}$ \\
\hline$\beta$-Caryophyllene & 1417 & 0.28 & 0.22 & & & 2.37 & 2.95 & 0.6 & 0.7 & 0.46 & 0.35 & I, MS, Co-GC \\
\hline Citronellyl propanoate & 1445 & 0.14 & 0.13 & & & & & & & & & $\mathrm{I}, \mathrm{MS}$ \\
\hline$\alpha$-Caryophyllene & 1451 & 0.08 & trace & & & 3.42 & 3.62 & & & & & $\mathrm{I}, \mathrm{MS}, \mathrm{Co}-\mathrm{GC}$ \\
\hline allo-Aromadendrene & 1459 & 0.08 & trace & & & & & & & & & $\mathrm{I}, \mathrm{MS}$ \\
\hline Geranyl propanoate & 1475 & 0.64 & 0.12 & & & & & & & & & $\mathrm{I}, \mathrm{MS}$ \\
\hline Germacrene D & 1479 & 0.80 & 0.76 & & & & & & & & & I, MS \\
\hline Viridiflorene & 1496 & 0.50 & 0.09 & & & & & & & & & $\mathrm{I}, \mathrm{MS}$ \\
\hline$\beta$-Bisabolene & 1506 & 0.12 & trace & & & & & & 0.1 & 0.18 & 0.13 & I, MS \\
\hline$\gamma$-Cadinene & 1512 & & & & & & & & & 0.83 & 0.77 & $\mathrm{I}, \mathrm{MS}$ \\
\hline Geranyl isobutanoate & 1515 & 0.21 & trace & & & & & & & & & I, MS \\
\hline$\delta$-Cadinene & 1522 & 0.16 & 0.13 & & & & & & 0.1 & & & I, MS \\
\hline Geranyl butanoate & 1562 & 0.28 & 0.35 & & & & & & & & & $\mathrm{I}, \mathrm{MS}$ \\
\hline Spathulenol & 1577 & $\underline{0.09}$ & $\underline{2.83}$ & 2.09 & 1.99 & & & & & & & $\mathrm{I}, \mathrm{MS}$ \\
\hline Caryophyllene oxide & 1583 & & & $\underline{0.41}$ & $\underline{2.23}$ & & & & & 0.97 & 1.31 & $\mathrm{I}, \mathrm{MS}$ \\
\hline 2-Phenyl ethyl tiglate & 1587 & 1.28 & 1.32 & & & & & & & & & $\mathrm{I}, \mathrm{MS}$ \\
\hline Viridiflorol & 1592 & & & & & 1.89 & 1.52 & & & & & $\mathrm{I}, \mathrm{MS}$ \\
\hline 1,10-di-epi-Cubenol & 1617 & 0.14 & trace & & & & & & & 0.10 & 0.18 & I, MS \\
\hline 10 -epi- $\gamma$-Eudesmol & 1622 & 4.50 & 5.78 & & & & & & & & & $\mathrm{I}, \mathrm{MS}$ \\
\hline 1-epi-Cubenol & 1630 & 0.10 & trace & & & & & & & & & $\mathrm{I}, \mathrm{MS}$ \\
\hline$\gamma$-Eudesmol & 1634 & 0.07 & trace & & & & & & & & & $\mathrm{I}, \mathrm{MS}$ \\
\hline$\tau$-Cadinol & 1640 & & & & & & & & & 1.36 & 0.63 & $\mathrm{I}, \mathrm{MS}$ \\
\hline Vulgarone B & 1651 & & & 11.41 & 12.60 & & & & & & & $\mathrm{I}, \mathrm{MS}$ \\
\hline$\alpha$-Eudesmol & 1653 & 0.40 & 0.35 & & & & & & & & & $\mathrm{I}, \mathrm{MS}$ \\
\hline Valerianol & 1655 & 0.56 & 0.74 & & & & & & & & & I, MS \\
\hline (E)-Citronellyl tiglate & 1668 & 0.10 & 0.02 & & & & & & & & & I, MS \\
\hline Geranyl tiglate & 1701 & 1.01 & 0.95 & & & & & & & & & $\mathrm{I}, \mathrm{MS}$ \\
\hline Total & & 98.25 & 98.07 & 93.88 & 95.46 & 98.18 & 97.2 & 96.7 & 97.2 & 97.90 & 97.12 & \\
\hline
\end{tabular}

${ }^{\mathrm{a}}$ Compouds listed in order of elution from an HP-5 MS capillary column

${ }^{b} \mathrm{RI}$ : Retention indices as determined on a HP-5 MS capillary column using a homologous series of n-alkanes (C9-C23) ${ }^{\mathrm{c}}$ Identification method: I=retention index, $\mathrm{MS}=$ mass spectrum, $\mathrm{Co}-\mathrm{GC}=$ coinjection with authentic compound.

${ }^{\mathrm{c}} \mathrm{M}=$ mycorrhizal, $\mathrm{NM}=$ non-mycorrhizal

${ }^{\mathrm{d}}$ Bold and underlined values are significantly different $(P=0.05)$ according to $T$ Test. 